\title{
Nyssomyia intermedia (Lutz \& Neiva) and Nyssomyia neivai (Pinto) (Diptera, Psychodidae, Phlebotominae) in a sympatric area: seasonal and nocturnal hourly rhythm in black and white modified Shannon traps
}

\author{
Eunice A. B. Galati ${ }^{1}$, Ana Maria Marassá ${ }^{2}$, Rute Maria Gonçalves-Andrade ${ }^{3}$, Edna Fátima Maria Bueno ${ }^{1}$, Byanca \\ R. Paiva ${ }^{4} \&$ Rosely S. Malafronte ${ }^{4,5}$
}

Departamento de Epidemiologia, Faculdade de Saúde Pública, Universidade de São Paulo. Av. Dr. Arnaldo 715, 01246-904 São Paulo-SP, Brazil. egalati@ usp.br

${ }^{2}$ Faculdade de Saúde Pública, Secção de Parasitoses Sistêmicas, Instituto Adolpho Lutz, Av. Dr. Arnaldo 355; 01246-904 São Paulo-SP, Brazil. anamarassa@usp.br

${ }^{3}$ Laboratório de Imunoquímica, Instituto Butantan, Av. Vital Brasil 1500, 05508-900 São Paulo-SP, Brazil. rutemgdeandrade@butantan.gov.br

${ }^{4}$ Instituto de Medicina Tropical de São Paulo, Laboratório de Protozoologia, Universidade de São Paulo, Av. Dr. Enéas Carvalho Aguiar 470, $05403-000$ São Paulo-SP, Brazil. byapaiva@usp.br

${ }^{5}$ Departamento de Doenças Infecciosas e Parasitárias, Faculdade de Medicina, Universidade de São Paulo, Av. Dr. Enéas Carvalho Aguiar 470, 05403-000 São Paulo-SP, Brazil. rmalafronte@usp.br

\begin{abstract}
Nyssomyia intermedia (Lutz \& Neiva) and Nyssomyia neivai (Pinto) (Diptera, Psychodidae, Phlebotominae) in a sympatric area: seasonal and nocturnal hourly rhythm in black and white modified Shannon traps. Captures with black and white Shannon traps were undertaken to identify aspects of the behavior of the two cryptic and sympatric species implicated as vectors of cutaneous leishmaniasis, Nyssomyia intermedia (Lutz \& Neiva, 1912) and Nyssomyia neivai (Pinto, 1926). The traps were installed side by side, monthly, from July 2001 to June 2002, from 18 to 07 hours, in a peridomicile of Iporanga municipality, state of São Paulo, Brazil. A total of 2,142 specimens were captured, Ny. intermedia (47.4\%) and Ny. neivai (50.5\%). The white trap was more attractive to both sexes of both species. Males of $N y$. neivai predominated $(70 \%)$ over those of $N y$. intermedia on the two traps; on the black trap, the females of $N y$. intermedia predominated (63.3\%) over those of $N y$. neivai $(36.7 \%)$. Seventy percent of the specimens of both species were captured between 18 and $24 \mathrm{~h}$. Females of $N y$. intermedia presented the highest peak at 19-20 h, and those of $N y$. neivai at 20-21 h. The highest hourly average for females of $N y$. intermedia on the black trap occurred in the winter and that for males in the summer. For $N y$. neivai, both sexes predominated in the summer. The two species probably transmit the cutaneous leishmaniasis in the area due to their great predominance.
\end{abstract}

KEYWORDS. Ecology; cutaneous leishmaniasis; Ribeira Valley; vectors.

RESUMO. Nyssomyia intermedia (Lutz \& Neiva) e Nyssomyia neivai (Pinto) (Diptera, Psychodidae, Phlebotominae) em área de ocorrência simpátrica: ritmo sazonal e horário noturno em armadilhas de Shannon modificadas nas cores branca e preta. Objetivando identificar aspectos do comportamento de duas espécies crípticas, simpátricas e implicadas na transmissão de leishmaniose tegumentar, Nyssomyia intermedia (Lutz \& Neiva, 1912) e Nyssomyia neivai (Pinto, 1926), procederam-se capturas com armadilhas de Shannon preta e branca, instaladas lado a lado, mensalmente, de julho/2001 a junho/2002, das 18-07 horas, em peridomicílio no município de Iporanga, Estado de São Paulo, Brasil. Um total de 2.142 espécimes foi capturado, $N y$. intermedia $(47,4 \%)$ e $N y$. neivai $(50,5 \%)$. A armadilha branca foi mais atrativa para ambos os sexos das duas espécies. Machos de $N y$. neivai predominaram (70\%) sobre os de $N y$. intermedia nas duas armadilhas; na preta, as fêmeas de $N y$. intermedia predominaram $(63,3 \%)$ sobre às de $N y$. neivai (36,7\%); 70\% dos espécimes de ambas as espécies foi capturado entre $18 \mathrm{~h}$ e $24 \mathrm{~h}$. Fêmeas de $N y$. intermedia apresentaram o maior pico das 19-20h e as de $N y$. neivai das 20-21h. Na armadilha preta, a maior média horária para as fêmeas de $N y$. intermedia ocorreu no inverno e para os machos, no verão; para $N y$. neivai, ambos os sexos predominaram no verão. Na branca, ambos os sexos de ambas as espécies foram mais atraídos no verão. A alta predominância de ambas as espécies sugere que estejam atuando na transmissão da leishmaniose cutânea na área.

PALAVRAS-CHAVE. Ecologia; leishmaniose tegumentar; Vale do Ribeira, vetores.

Nyssomyia intermedia (Lutz \& Neiva, 1912) and $N y$. neivai (Pinto, 1926) are morphologically very similar (Andrade-Filho et al. 2006), so much so that Ny. neivai has been proposed as a junior synonym of $N y$. intermedia by Dyar (1929) and Pinto (1930), a status which was maintained until their differentiation based on morphological and molecular approaches was proposed by Marcondes (1996). The morphological distinction was based mainly on the appearance of the spermathecae and the number of the horizontal teeth of the cibarium of the females, but it was not applicable to the male characteristics, despite the morphometric and artificial neural network analysis undertaken (Marcondes \& Borges 2000). Nonetheless, due to the great polymorphism of the two species, the characteristics proposed by Marcondes (1996) for the distinction of their females could not always consistently be applied. A more convincing set of characters for the distinction of the males and the females of the two species has been presented by Andrade-Filho et al. (2003). 
The allopatric distribution of the two species over a vast area has made it possible to distinguish the information regarding each species from that concerning the other. They are anthropophilic, Ny. neivai (Gomes et al. 1989; Pinto et al. 2001) and Ny. intermedia (Aguiar et al. 1996; Souza et al. 2001, 2005) have been found to be naturally infected by trypanosomatids, and both Ny. neivai (Forattini \& Santos 1952; Forattini et al. 1972; Casanova et al. 1995; Córdoba-Lanus et al. 2006) and Ny. intermedia (Aragão 1922; Rangel et al. 1984; Pita-Pereira et al. 2005) are suspected of transmitting the agents of American cutaneous leishmaniasis, mainly in the Brazilian Southeastern and Southern regions (Rangel \& Lainson 2003).

Although some studies have been made into behavioral aspects of these species (Forattini et al. 1976; Gomes et al. 1980, 1982, 1983, 1986, Gomes \& Galati 1987; Domingos et al. 1998; Taniguchi et al. 2002) in areas of the Ribeira Valley where they are sympatric (Marcondes et al. 1998; AndradeFilho et al. 2007), those studies were carried out before the two species had been differentiated.

At the beginning of a project to identify the phlebotomine fauna and some ecological aspects of its population in the Speleological Province of the Ribeira Valley, in the Paranapiacaba range, undertaken from January 2001 to December 2003, in one of the localities of the Parque Estadual do Alto Ribeira (PETAR) selected for the study, i.e. the Serra district, Iporanga municipality, where the tourists that visit the caves stay, it was discovered that Nyssomyia neivai (Pinto, 1926) and Ny. intermedia (Lutz \& Neiva, 1912) are sympatric.

The Ribeira Valley region, with 1,174 cases of human American cutaneous leishmaniasis registered between 1998 and 2006 and an annual average coefficient of 47.71/100,000 inhabitants, has one of highest incidences of cases in the State of São Paulo. For Iporanga municipality, of which the Serra district is part, in that same period a total of 63 cases were reported and the coefficient there was still higher (53.14/100,000 inhabitants), two and four of the cases reported occurring, respectively, during the years 2001 and 2002 (CVE 2007).

The information on diversity of species, relative abundance, anthropophily and zoophily, identification of the natural infection by the agent associated with the blood meal at an advanced stage of digestion or infective forms in the anterior midgut of the wild female, are all of relevance in determining whether a particular sandfly species is a Leishmania vector in a specific area (Feliciangeli 1987; Killlick-Kendrick 1990), besides the knowledge of its hourly rhythm and seasonal activity.

So the present study, containing observations on the nocturnal activity rhythm, the seasonal variation, the respective attractiveness of the black and white modified Shannon traps and the natural infection by flagellates for the two species in a peridomicile of the Serra district, was undertaken for the purpose of identifying behavioral characteristics of theirs which may help to understand their roles as cutaneous leishmaniasis vectors, in a sympatric area.

\section{MATERIAL AND METHODS}

Study area. The Serra district, $240 \mathrm{~m}$ a.s.l., is situated on the banks of the Betari river in the municipality of Iporanga $\left(24^{\circ} 21^{\prime} \mathrm{S}, 48^{\circ} 20^{\prime} \mathrm{W}\right)$, state of São Paulo, Brazil. This district, with about 110 dwellings (Giatti et al. 2004) situated within a narrow strip along the road that links Iporanga and Apiaí cities, has an economy based mainly on inns catering for tourists who visit the caves of the Santana nucleus, 4 $\mathrm{km}$ away. This speleological nucleus lies within the Parque Estadual do Alto Ribeira (PETAR), an Atlantic forest reserve on the Serra de Paranapiacaba in the Ribeira Valley region, in the south of São Paulo state. This reserve is situated in a transitional area between the so-called "Atlantic Plateau" and the coastal plain.

The climate is also transitional between a tropical low altitude one and a temperate one of intermediate altitude (Nimer 1977) and is classified as sub-tropical and highly humid with no dry season. The annual rainfall average from 1970-1996 was $1,963.3 \mathrm{~mm}$, of which $681.8 \mathrm{~mm}$ fell in the less intense (April -September) and 1,281.5 $\mathrm{mm}$ in the more intense rainy season (October - March). A coastal, hygrophilous, non-deciduous forest, with the highest trees attaining 25-30 m, large numbers of lianas, epiphytes, tree ferns and palms cover the slopes (Karmann \& Ferrari 2002).

The research was undertaken in a peridomicile of a smallholding ( $c a .1 / 2$ ha) with a dwelling in which a family of four lived. During the whole research period there were a hen-house and goose-shelter close to the dwelling. Near the dwelling there were several fruit trees and, about $30 \mathrm{~m}$ away, several old and very high native trees with holes in their trunks and bromeliads on their branches and trunks. Around this smallholding there were others of similar characteristics, with cattle on one of them. Between these smallholdings, located in the Betari valley, and the forested slope about 300 $\mathrm{m}$ away, there was an area of subsistence agriculture (beans, manioc, maize and other crops).

For the captures of the phlebotomines, the black and white modified Shannon light traps (Galati et al. 2001) were installed monthly from July 2001 to June 2002 , between $18.00 \mathrm{~h}$ and $07.00 \mathrm{~h}$., side by side, with inversion of their positions for each successive collection. The traps were installed among fruit and native trees, $10 \mathrm{~m}$ from the dwelling and $40 \mathrm{~m}$ from a stream tributary of the left bank of the Betari river. Two gas lanterns ( 350 watts) and manual lanterns (15 ampères, 6 volts) were used as light sources. The captures were made on each trap at hourly intervals. When the insects were few they were captured and maintained individually in a flask. This was covered with a piece of nylon cloth under a plastic lid with a hole in the middle of it. Through this hole a small ball of cotton wool soaked in a sugar solution was introduced and which served as a source of energy and humidity for the insect, keeping it alive until dissection in the case of female. When there were many insects a 6 volts electric aspirator was used and the insects thus captured were freed into a small cage and then the female were transferred individually to that flask. The males were died with chloroform. 
The live insects were maintained in a styrofoam box with a thin humid lining of plaster of Paris until the dissection of the females for the investigation of natural infection by flagellates could be performed. The females after being immobilised with ethyl ether were individually transferred to drops of saline solution on slides, dissected, covered with a cover-glass and examined under a microscope to ascertain the presence of flagellates and identify the sandfly. After this dissection the slides were immersed in isopropanol in a Falcon tube, where the specimens were maintained in pools of the same species and date, for the investigation of Leishmania by the PCR test of a sample captured in 2002. The PCR test was applied in accordance with the protocol described by Paiva et al. (2006).

The identification of the sandflies took place in the Public Health Entomology/ Phlebotominae Laboratory of the Faculdade de Saúde Pública of the University of São Paulo, in accordance with Galati's keys (2003).

Rainfall data for the municipality of Iporanga were obtained from the meteorological station situated in the Betari river valley on the Serra dos Motas (Sistema de Informações para o Gerenciamento de Recursos Hídricos do Estado de São Paulo - SIGRH 2007) and those for temperature from the neighboring municipality of Eldorado (Centro Integrado de Informações Agrometeorológicas - CIIAGRO 2007).

Statistical analysis. The relative attractiveness of the black and white modified Shannon traps, by species and sex, was assessed by the Chi-squared $\left(\chi^{2}\right)$ test for absolute frequencies. The hourly frequency and the seasonal distribution were obtained by Williams' geometric average (Haddow 1960). Spearman's correlation coefficient (SPSS for Windows, Release 5.02 Program) was used to seek possible correlations between the numbers of insects captured and the monthly rainfall and temperatures (monthly average, minimum on the capture days and absolute monthly minimum).

\section{RESULTS}

The species with their respective numbers of specimens captured in the 12 collections undertaken with the white and black modified Shannon traps are presented in Table I. A total of 2,142 specimens were collected, of which 2,097 (97.9\%) belonged to the genus Nyssomyia. Pintomyia fischeri contributed with (1.26\%), Migonemyia migonei $(0.65 \%)$, Brumptomyia sp. $(0.10 \%)$ and a single specimen of Lutzomyia longipalpis (0.05\%). Considering the two traps together an average of 89.3 insects/trap and 6.9 insects/hour were captured.

In the genus Nyssomyia, the number of specimens of $N y$. neivai attracted to the two traps together predominated over that of $N y$. intermedia ( $51.5 \%$ and $48.5 \%$, respectively), though with no statistical significance $\left(\chi^{2}=1.89 ; \mathrm{p}>0.05\right)$. The females of the two species were more attracted by both traps than were the males, but the traps' attractiveness for $N y$. intermedia was considerably greater (female/male ratio: black - 6.5:1.0; white - 4.4:1.0) than for Ny. neivai (black -1.7:1.0; white -1.9:1.0) (Table II).

For the males of both species, the white trap was
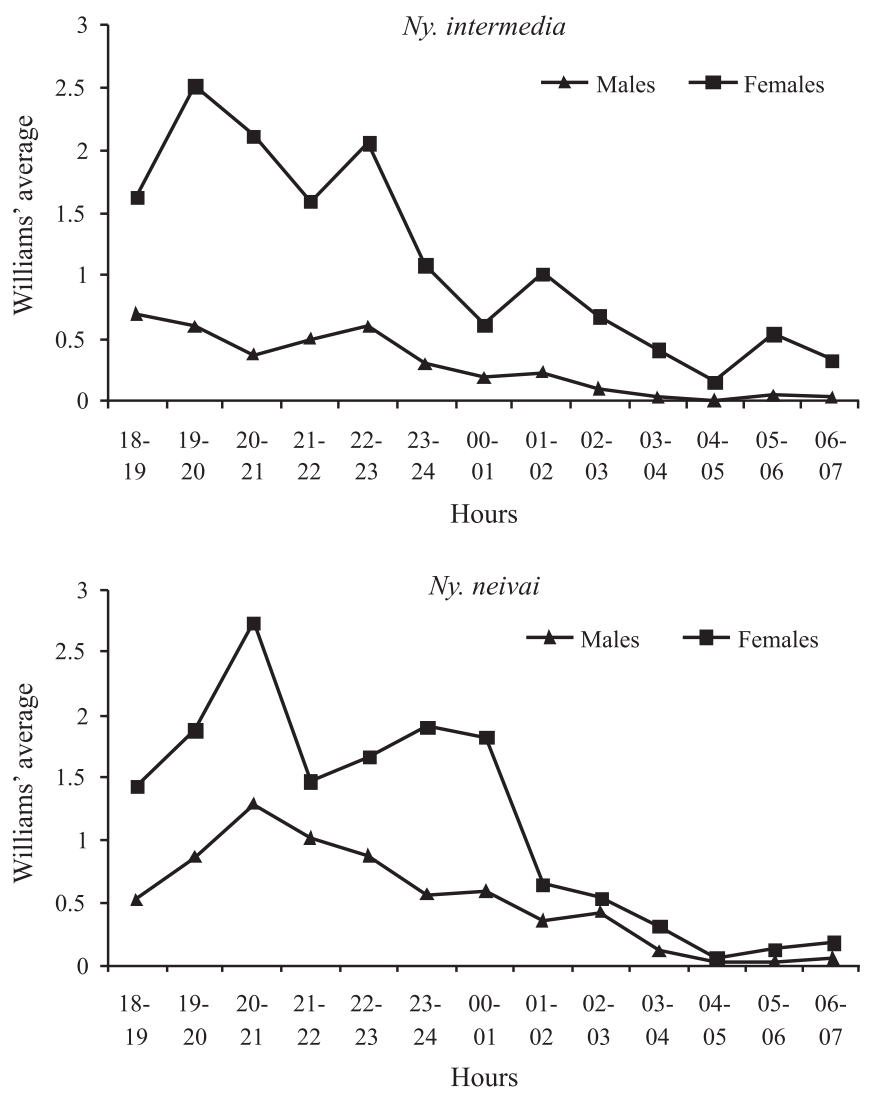

Fig. 1. Male and female nocturnal hourly $(18.00-07.00 \mathrm{~h})$ rhythm of $N y$. intermedia and $N y$. neivai captured with black and white Shannon traps. Serra district, Iporanga municipality, July 2001 - June 2002.

significantly $(\mathrm{p}<0.001)$ more attractive $(70.0 \%)$ than the black $(30.0 \%)$. As regards the females, the white trap attracted both species with practically the same frequency ( $N y$. intermedia $49.7 \%$ and $N$. neivai $50.3 \% ; \mathrm{p}>0.05$ ), while the attractiveness of the black trap was significantly greater $(\mathrm{p}<0.001)$ for $N y$. intermedia (63.3\%) than for $N y$. neivai (36.7\%).

The nocturnal hourly distributions of $N y$. intermedia and Ny. neivai are presented in Figs. 1-3.

The nocturnal hourly rhythm independently of the color of the traps is present in Fig. 1. More than $70.0 \%$ of the specimens of both species and sexes were captured between 18.00 and $00.00 \mathrm{~h}$. The females of $N y$. intermedia presented four peaks during the study period, the highest of which occurred from 19.00-20.00 $\mathrm{h}$. and the three others, progressively lower, from 22.00-23.00 h, 01.00-02.00 $\mathrm{h}$ and 05.00-06.00 $\mathrm{h}$, while the males were more frequent from 18.00-19.00 h, and presented modest peaks coincident with the three latest female peaks. Whereas both sexes of $N y$. neivai presented a conspicuous peak from 20.00-21.00 h, the females presented another peak, smaller than the former one, from $23.00-01.00 \mathrm{~h}$; the males had modest peaks from 00.00-01.00 $\mathrm{h}$ and $02.00-03.00 \mathrm{~h}$. The females of both species presented some activity from 06.00-07.00 hours, though that of $N y$. intermedia was slightly greater.

In the Fig. 2 is presented the nocturnal hourly rhythm of the two species, by sex, according to the color of the 

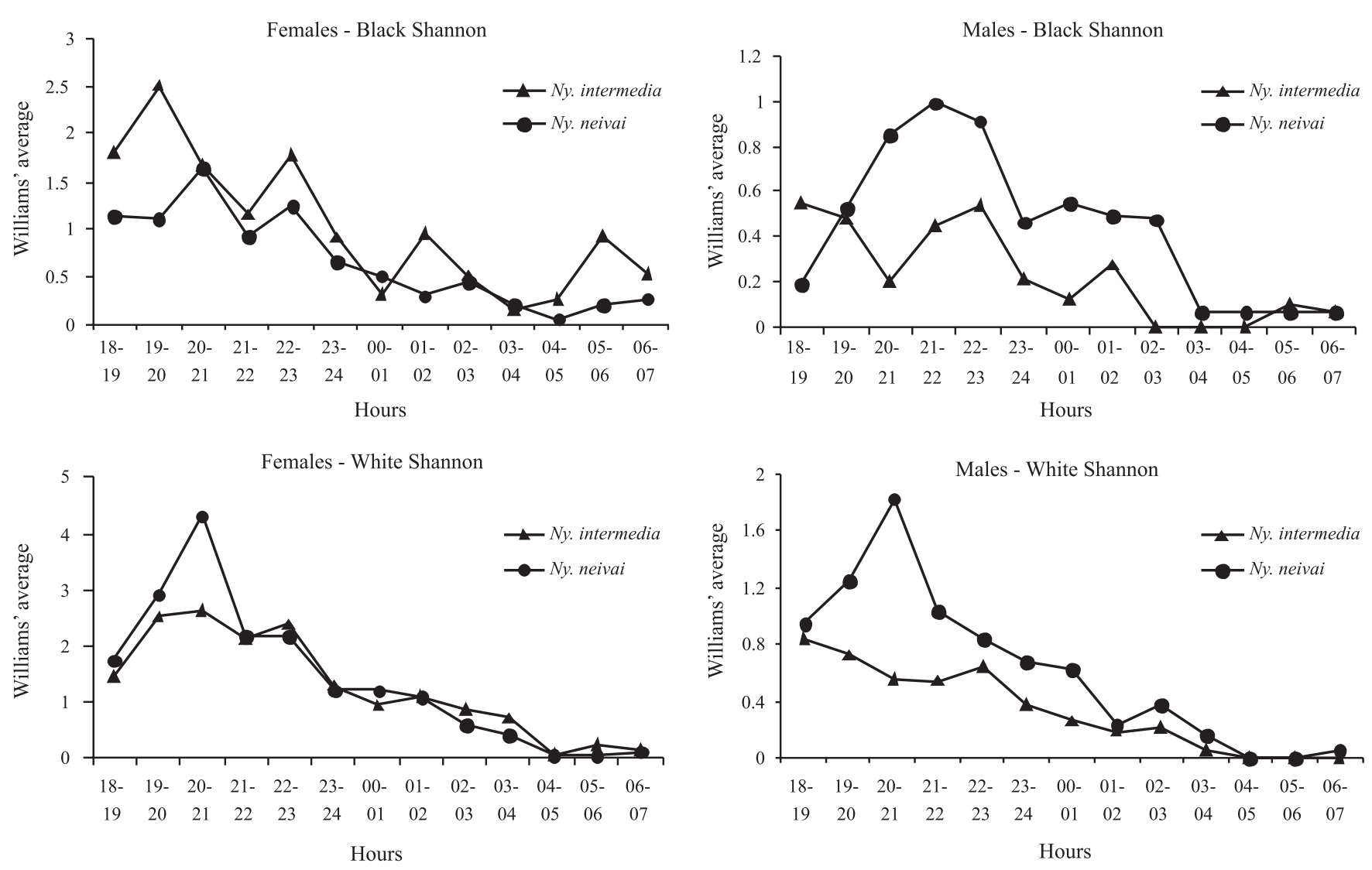

Fig. 2. Comparison of the nocturnal hourly $(18.00-07.00 \mathrm{~h})$ rhythm between the same sex of Ny. intermedia and $N y$. neivai by color of the Shannon traps. Serra district, Iporanga municipality, July 2001 - June 2002.

traps. On the black trap, the females of $N y$. intermedia and $N y$. neivai presented four peaks of activity, with only one of these coinciding at 22.00-23.00 h. For the three other peaks, those for $N y$. neivai occurred one hour later than those of $N y$. intermedia. For the males no coincident peak was observed for the two species. On the white trap, the females of the two species exhibited more distinct behavior than on the black trap; Ny. intermedia presented the highest frequencies from 19.00$23.00 \mathrm{~h}$ while for $N y$. neivai the peak occurred from 19.00$20.00 \mathrm{~h}$. The males also presented different tendencies in the first half of the night: $N y$. intermedia had its highest average at the beginning of the capture period and another smaller peak at 22.00-23.00 $\mathrm{h}$ while the peak of $N y$. neivai occurred from $20.00-21.00 \mathrm{~h}$. Both species presented practically the same behavior during the second half of the night.

Fig. 3 shows the attractiveness of each trap for each sex of the two species, in accordance with the nocturnal hourly rhythm. In the first half of the period of observation, the males of $N y$. intermedia and $N y$. neivai were more attracted to the white trap than to the black, while in the second half, in some intervals, the opposite was true. For the females, $N y$. intermedia was more attracted to the white trap during the majority of the intervals, but had a similar frequency on both traps at 19.00-20.00 $\mathrm{h}$ and a higher peak on the black trap during the interval $04.00-06.00 \mathrm{~h}$. Females of $N y$. neivai were more attracted to the white trap than to the black, this difference being more marked at 19.00-20.00 $\mathrm{h}$, when the main peak of both species occurred.

Fig. 4 presents the Williams' average and the number of specimens of both sexes of the two species captured on both traps. Ny. intermedia presented four peaks, those at 19.00$20.00 \mathrm{~h}$ and $22.00-23.00 \mathrm{~h}$ being the highest and almost equal, the two other lower ones occurring at $01.00-02.00 \mathrm{~h}$ and $05.00-06.00 \mathrm{~h}$. The largest numbers of insects were captured at 18.00-20.00 h, without there being any coincidence with the highest averages, thus showing the absence of any correspondence between these values, as the larger numbers are simply a reflection of sporadically greater frequencies. For $N y$. neivai, with the exception of the first period, 18.00$19.00 \mathrm{~h}$, there occurred a coincidence between the magnitude of the averages and of the numbers, the highest peak of the average and the largest number occurring at 20.00-21.00 h.

The monthly distribution of $N y$. intermedia and $N y$. neivai is shown in Fig. 5. Both species presented practically the same tendency, the lowest frequencies being captured in September and April, with the highest peak in March. Besides this peak, Ny. intermedia presented two others, in July 2001 and in June 2002, with practically the same number of insects in each. For Ny. neivai three other peaks occurred: in July 2001, January 2002 and May-June 2002. The total monthly rainfall and that on the days of capture during the period from July 2001 to June2002 in Iporanga municipality are shown in 

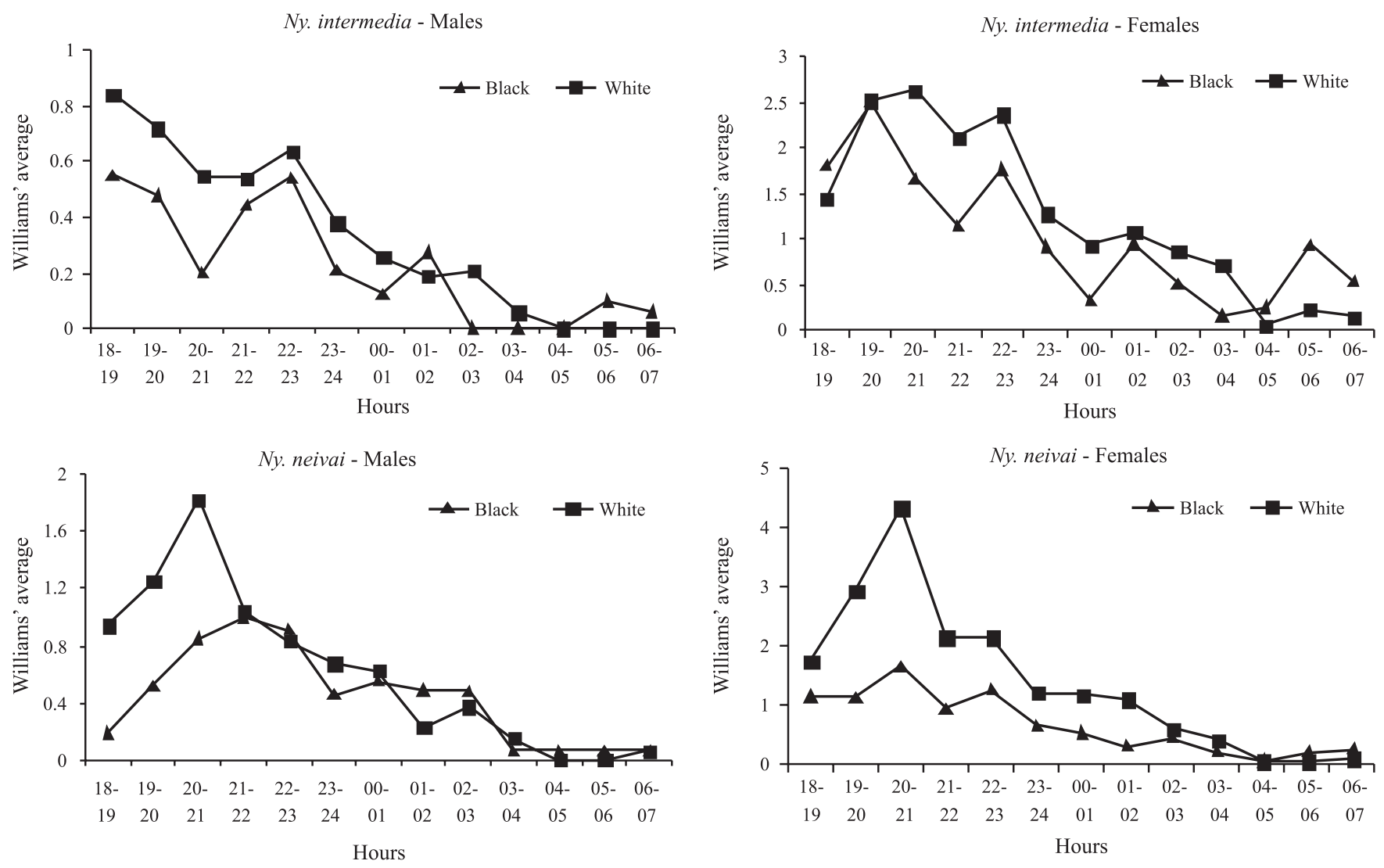

Fig. 3. Attractiveness of the black and with Shannon traps for each sex of of $N y$. intermedia and $N y$. neivai, in accordance with the nocturnal hourly (18.00 07.00 h). Serra district, Iporanga municipality, July 2001 - June 2002.

Fig. 6. The peaks of July 2001, March and June 2002 coincide with moderate or low rainfall; however, the high precipitation on the two days of capture in March is remarkable. The rain began at $02.30 \mathrm{~h}$ in the morning of the capture.

When Spearman's correlation coefficients were calculated as between the total number of males and females captured monthly in both traps in relation to the monthly rains $(\mathrm{n}=$ 12) and that total as related to the temperatures (mean of the month, minimum on the capture day and absolute minimum of the month) $(\mathrm{n}=12)$, a low negative correlation of $\mathrm{Ny}$. intermedia with rainfall $(\mathrm{rS}=-0.10$; Sig. 762$)$ and a low positive correlation of $N y$. neivai with rainfall $(\mathrm{rS}=0.17$; Sig. 0.587 ) were observed. There were extremely low negative correlations of $N y$. intermedia and $N y$. neivai with mean monthly temperatures $(\mathrm{rS}=-0.06$; Sig. 0.854 and -0.04 ; Sig. 0.905 , respectively). $N y$. intermedia and $N y$. neivai showed negative correlations with the minimum temperatures on the days of capture, that of $N y$. intermedia being moderate $(\mathrm{rS}=$ 0.33; Sig. 0.297) and that of Ny. neivai low ( $\mathrm{rS}=-0.28$; Sig. 0.379 ). Negative and low correlations were observed between both species and the minimum monthly temperatures: $N y$. intermedia $(\mathrm{rS}=-0.12$; Sig. 0.704) and $N y$. neivai $(\mathrm{rS}=$

Table I. Frequencies of specimens, by species and sex, captured with white and black modified Shannon traps, monthly, from 18.00 - 07.00 h, July 2001 - June 2002, in the peridomicile, Serra district, Iporanga municipality, state of Sao Paulo, Brazil.

\begin{tabular}{|c|c|c|c|c|c|c|c|c|c|c|c|c|c|c|c|}
\hline \multirow{3}{*}{$\begin{array}{l}\text { Trap } \\
\text { Species }\end{array}$} & \multirow{3}{*}{ Sex } & \multicolumn{6}{|c|}{ White } & \multicolumn{6}{|c|}{ Black } & \multirow{2}{*}{\multicolumn{2}{|c|}{ Total }} \\
\hline & & \multicolumn{2}{|c|}{ Males } & \multicolumn{2}{|c|}{ Females } & \multicolumn{2}{|c|}{ Both sexes } & \multicolumn{2}{|c|}{ Males } & \multicolumn{2}{|c|}{ Females } & \multicolumn{2}{|c|}{ pigsty } & & \\
\hline & & $\mathrm{N}$ & $\%$ & $\mathrm{~N}$ & $\%$ & $\mathrm{~N}$ & $\%$ & $\mathrm{~N}$ & $\%$ & $\mathrm{~N}$ & $\%$ & $\mathrm{~N}$ & $\%$ & $\mathrm{~N}$ & $\%$ \\
\hline$B r$. sp. & & - & - & 2 & 0.2 & 2 & 0.1 & - & - & 1 & 0.2 & 1 & 0.1 & 3 & 0.14 \\
\hline Lu. longipalpis & & - & - & - & - & - & - & - & - & 1 & 0.2 & 1 & 0.1 & 1 & 0.05 \\
\hline Mg. migonei & & 1 & 0.3 & 3 & 0.2 & 4 & 0.3 & 5 & 2.5 & 5 & 0.8 & 10 & 1.2 & 14 & 0.65 \\
\hline Ny. intermedia & & 108 & 30.0 & 477 & 49.1 & 585 & 43.9 & 58 & 29.0 & 374 & 61.3 & 432 & 53.3 & 1017 & 47.48 \\
\hline Ny. neivai & & 249 & 69.4 & 483 & 49.7 & 732 & 55.0 & 131 & 65.5 & 217 & 35.5 & 348 & 43.0 & 1080 & 50.42 \\
\hline Pi. fischeri & & 1 & 0.3 & 8 & 0.8 & 9 & 0.7 & 6 & 3.0 & 12 & 2.0 & 18 & 2.3 & 27 & 1.26 \\
\hline Total & & 359 & 100.0 & 973 & 100.0 & 1332 & 100.0 & 200 & 100.0 & 610 & 100.0 & 810 & 100.0 & 2142 & 100.0 \\
\hline
\end{tabular}

Br.: Brumptomyia; Lu.: Lutzomyia; Mg.: Migonemyia; Ny.: Nyssomyia; Pi.: Pintomyia. 


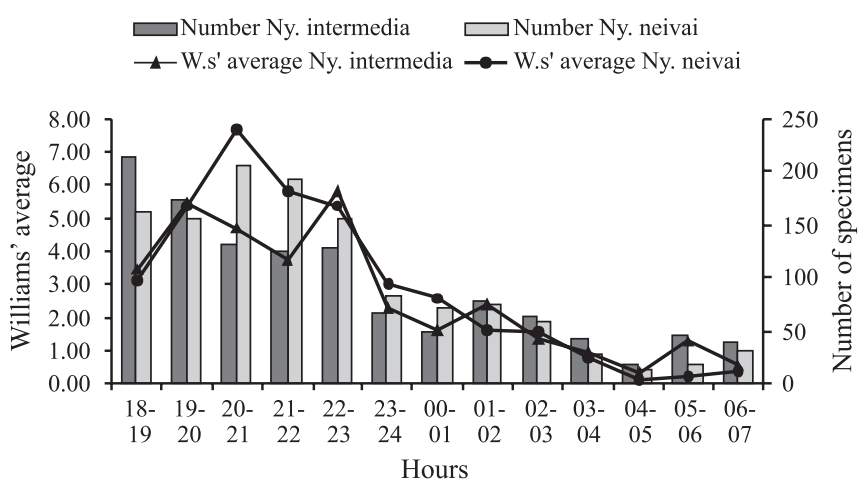

Fig. 4. Nocturnal hourly rhythm of both sexes of $N y$. intermedia and $N y$. neivai captured with both black and white Shannon traps installed in peridomicile, from July 2001 to June 2002. Serra district, Iporanga municipality.

- 0.10; Sig. 0.753). Thus it is possible to identify a greater correlation, though with no statistical significance $(\mathrm{p}>0.05)$, as between $N y$. intermedia and the drier and colder periods than occurred with $N y$. neivai.

The seasonal distribution is presented in Figs. 7 and 8 . In Fig. 7 the seasonal averages of $N y$. intermedia and $N y$. neivai obtained from the total number of specimens of both sexes, captured on the black and white traps, are plotted. For both species, the summer presented the highest averages, the difference in relation to all the other seasons being statistically significant for $N y$. neivai $(\mathrm{p}<0.001)$, whereas for $N y$. intermedia it was only significant for the spring $(\mathrm{p}<$ 0.001 ). Beyond this difference, $N y$. intermedia also presented a different distribution with statistical significance as between winter and spring and spring and autumn $(\mathrm{p}<0.001)$. In the comparison between the two species, as regards the same season, there were statistically significant differences $(\mathrm{p}<$ 0.05 ) in spring and summer.

The hourly averages by season, species, sex and trap are presented in Fig. 8. On the black trap, females of Ny. intermedia predominated in the winter, the males in the summer. For $N y$. neivai, males and females predominated in the summer, though the frequency of the females in the winter was almost equivalent to that of the summer. On the white trap both species and both sexes were most attracted in the summer, with more conspicuous differences for the males than the females. The Spearman correlation coefficients calculated for the seasonal Williams' geometric averages of the insect numbers in relation to rainfall $(n=4)$, and the numbers of insects in terms of temperature $(n=4)$, gave a moderate negative correlation

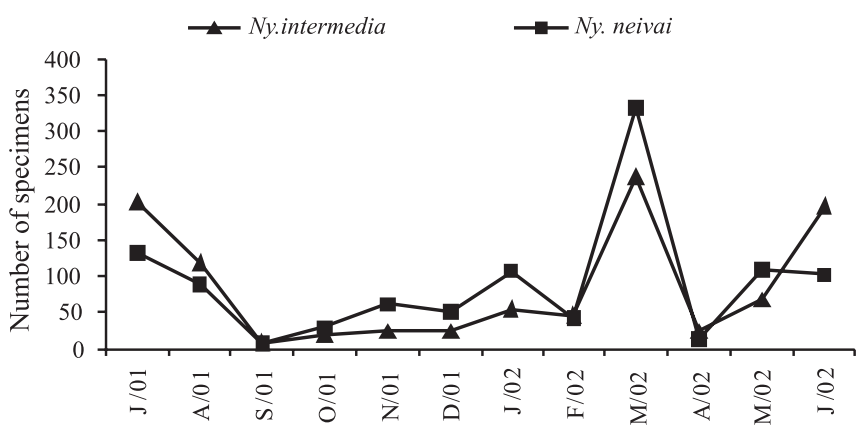

Fig. 5. Monthly distribution of both sexes of $N y$. intermedia and $N y$. neivai captured with both black and white Shannon traps from $18.00-00.00 \mathrm{~h}$. in the peridomicile, Serra district, Iporanga municipality, July 2001 - June 2002 .

of monthly rainfall and $N y$. intermedia $(\mathrm{rS}=-0.40$; Sig. 0.6 ) and an absence of correlation with $N y$. neivai $(\mathrm{rS}=0.0)$. As regards the mean monthly temperature, there occurred a strong positive correlation for $N y$. neivai $(\mathrm{rS}=0.80$; Sig. 0.2$)$ and a moderate positive correlation for $N y$. intermedia $(\mathrm{rS}=$ $0.40 ; n=4$; Sig. 0.6). Ny. intermedia showed no correlations with minimum temperatures on the days of capture $(\mathrm{rS}=0.0)$ but $N y$. neivai presented a moderate positive correlation (rS $=0.40 ; \mathrm{n}=4$; Sig. 0.06); Ny. intermedia showed a substantial positive correlation $(\mathrm{rS}=0.6 ; \mathrm{n}=4$; Sig. 0.4$)$ and $N y$. neivai a strong positive correlation as regards the absolute minimum monthly temperatures $(\mathrm{rS}=0.8 ; \mathrm{n}=4$; Sig. 0.2$)$.

A total of 1,135 females were dissected for the investigation of natural infection by flagellates, 631 being of Ny intermedia (black: 287; white: 344), 493 of $N y$. neivai (black: 139; white: 354) and 11 of Pi. fischeri (black: 7; white: 4), with negative results. The PCR tests for identification of Leishmania species made on 392 females of $N y$. intermedia and 340 of $N y$. neivai distributed in 10 pools of each species also produced negative results.

\section{DISCUSSION}

The great similarity between the females of $N y$. intermedia and $N y$. neivai and their polymorphism made their initial identification difficult. However, based on the specimens captured in the same study area, but before the beginning of the observations with the two traps, it was possible to distinguish between them by their spermathecae: Ny intermedia presents the base of the terminal knob conspicuously wider than the

Table II. Number of specimens of $N y$. intermedia and $N y$. neivai, by sex, captured with white and black Shannon traps installed side by side, monthly, from 18.00 - 07.00 h, July 2001 - June 2002, in the peridomicile, Serra district, Iporanga municipality.

\begin{tabular}{|c|c|c|c|c|c|c|c|c|c|}
\hline \multirow{2}{*}{$\begin{array}{l}\text { Species } \\
\text { Trap/Sex }\end{array}$} & \multirow[b]{2}{*}{ q } & \multicolumn{3}{|c|}{ Nyssomyia intermedia } & \multicolumn{4}{|c|}{ Nyssomyia neivai } & \multirow[b]{2}{*}{ Total } \\
\hline & & $\hat{0}$ & Total & ㅇ/ठ심 & q & $\widehat{\sigma}$ & Total & $+1 / 0^{2}$ & \\
\hline White & 477 & 108 & 585 & 4.4 & 483 & 249 & 732 & 1.9 & 1317 \\
\hline Black & 374 & 58 & 432 & 6.5 & 217 & 131 & 348 & 1.7 & 780 \\
\hline Total & 851 & 166 & 1015 & 5.19 & 700 & 380 & 1080 & 1.84 & 2097 \\
\hline$\chi^{2}$ & 15.50 & 15.06 & 23.06 & - & 101.08 & 36.64 & 136.53 & - & 137.64 \\
\hline$\stackrel{\sim}{\mathrm{P}}$ & $<0.001$ & $<0.001$ & $<0.001$ & - & $<0.001$ & $<0.001$ & $<0.001$ & - & $<0.001$ \\
\hline
\end{tabular}




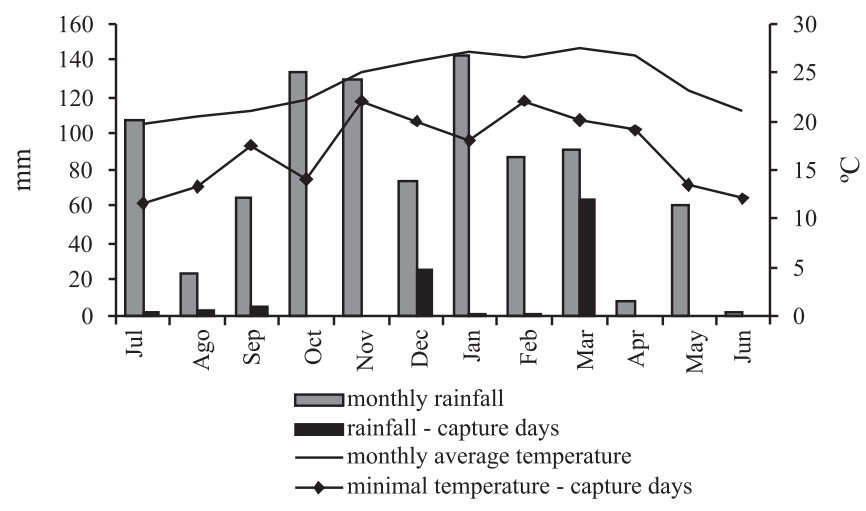

Fig. 6. Rainfall: monthly average and rainfall on capture days in Iporanga municipality and temperature: monthly average and minimum on capture days in Eldorado municipality, during period from July 2001 to June 2002.

width of the individual sperm duct at the junction with the spermatheca, while in Ny. neivai both structures are of the same width; moreover, $N y$. intermedia presents more robust spermathecae than $N y$. neivai. Male specimens of both species from allopatric areas were compared and it was seen that they presented distinct tips of the genital filaments. The consistency of these characteristics in the differentiation of the two species was confirmed in a more comprehensive sample which also included specimens from other areas (AndradeFilho et al. 2003).

The carbon dioxide and water vapour exhaled by the host and its odour, image and heat were identified as stimulating the host-seeking responses of mosquitoes (McIver 1982) and presumably also of other nematocerous biting flies (Gibson \& Torr 1999). Thus, the Shannon traps installed in the peridomicile, having as visual stimuli the light emitted, the trap itself and the body of the human being; as chemical stimuli the kairomones (carbon dioxide and the odors) expelled by the human being, as also the increase in heat due to the presence of the gas lanterns and the human being and the humidity of the air that is usually greater at night (Gibson \& Torr 1999), together created an artificial environment especially attractive to the anthropophilic sandflies. The Shannon traps frequently attracted these sandflies in great numbers, with a predominance of females over males (Alexander 2000). So considering the conspicuous and practically equivalent predominance in the peridomicile of $N y$. neivai and $N y$. intermedia, when both traps are considered together, their anthropophily as observed for Ny. neivai by Gomes et al. (1989) and Pinto et al. (2001) and for Ny. intermedia by Aguiar et al. (1996) and Souza et al. $(2001,2005)$ and the fact that they have been found to be naturally infected by flagellates by several authors: Ny. neivai (Forattini \& Santos 1952; Forattini et al. 1972; Casanova et al. 1995; Córdoba-Lanus et al. 2006) and $N y$. intermedia (Aragão 1922; Rangel et al. 1984; Pita-Pereira et al. 2005), has led us to suggest their participation as vectors of the cutaneous leishmaniasis in the area, since in the Ribeira Valley the transmission has been identified as occurring in the domiciliary and/or the extra-forest environment (Gomes et al.1986; Gomes \& Galati 1989).
The process of host-seeking, blood feeding and landing of the flies in view of the related internal and external stimuli, in accordance with Browne \& Bennett (1981), consists of four phases: I) appetitive behavior, with five stages, relating to the habitat of the bait: a) selection of the habitat, b) upwind orientation, c) near orientation, d) landing and e) crawling and entering; II) consummatory reaction - probing and feeding; III) cessation of feeding and IV) physiological state of rest. Thus the Shannon trap may in this case be considered as sheltering the human collector within it. So it may be presumed that the sandflies, after selecting the habitat (black or white trap) and landing on its walls, await an opportunity to feed on the human being inside the trap (Galati et al. 2001). So the greater attraction of both traps for females of $N y$. intermedia rather than for their males (female/male ratio $=4.4: 1.0$ on the white and 6.5:1.0 on the black trap) in comparison with that for the two sexes of $N y$. neivai (white 1.9:1.0; black 1.7:1.0) suggests that $N y$. intermedia's breeding or resting sites may be situated further away than those of Ny. neivai, perhaps in an area of more dense vegetation, and that a smaller number of males follow them in the search for their blood meal. The female/ male ratio (1.52:1.0) of $N y$. intermedia captured on a white Shannon trap in a peridomicile, $100 \mathrm{~m}$ from primary forest on the north coast of São Paulo state (Brito et al. 2002) seems to corroborate this point of view, as also does that for $N y$. neivai (2.36:1.0) captured also on white Shannon traps in a modified residual woodland in the north of Paraná state (Teodoro et al. 1991), this latter ratio thus being close to that found on the white trap in this present study. The greater attractiveness of the black traps for $N y$. intermedia than for $N y$. neivai seems also to be due to the former's greater dependence on a more shady and humid environment. The higher frequency of Lutzomyia almerioi, a troglophile species, on the black trap, seven times greater than that on the white trap (Galati et al. 2001), seems to lend support to this hypothesis as also does the distribution, in the Southeastern Region, of $N y$. intermedia, more closely associated with the coastal (more humid) area, while $N y$. neivai is found in the (drier) interior (Marcondes et al. 1998; Andrade-Filho et al. 2007).

Reinforcing this hypothesis is the fact that the hourly

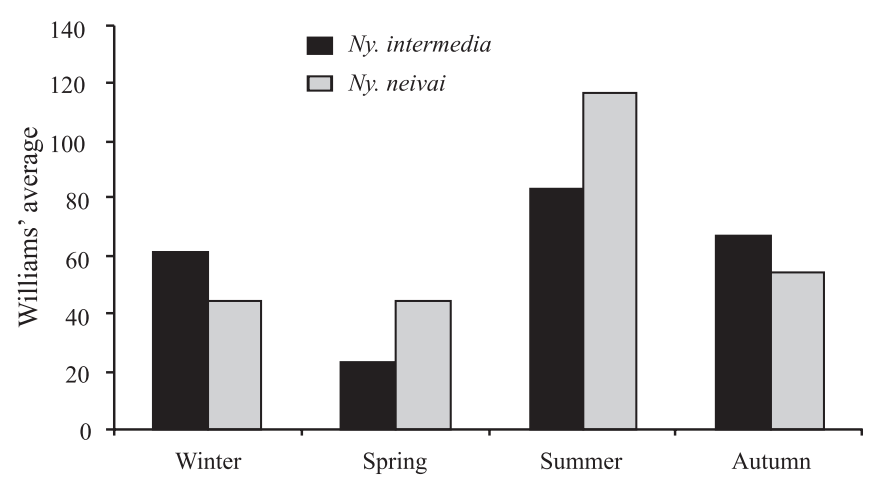

Fig. 7. Average of the total of specimens, males and females, of $N y$. intermedia and $N y$. neivai captured with both black and white Shannon traps, by season of year, in the peridomicile, Serra district, Iporanga municipality, July 2001 - June 2002. 
rhythm curves exhibited by females and males of $N y$. intermedia on the black trap and those of $N y$. neivai on the white trap have a more closely similar tendency than is true of the opposite (Fig. 2). Another contrasting behavior observed in the curves of hourly rhythm is that dusk is more stimulating for the males and dawn for the females of $N y$. intermedia than for those of $N y$. neivai and this also may indicate that the former species lives in a more shady environment where there are greater contrasts in the intensity of the light than in a more degraded one.

Both species are more frequent in the first period of the night, i.e. before $00.00 \mathrm{~h}$. This datum is in accordance with that related for Ny. intermedia (Brito et al. 2002) captured on a Shannon trap in a peridomicile on the coast of São Paulo state and also on human bait in a peridomicile in the state of Rio de Janeiro (Souza et al. 2005), but differs from the results found in a forested area in this latter study. This greater frequency in the first period of the night was also observed for $N y$. neivai in the north of the Paraná state in forested and anthropic environments, this last possessing the greatest proportion (94.9\%) of insects (Massafera et al. 2005), and in the southwest of the state of São Paulo where the specimens occurred in practically equal numbers on a Shannon trap in both periods (Condino et al.1998). However, in this present study, the peaks of $N y$. intermedia during the night all preceded those of $N y$. neivai by one hour, the most evident being at 19.00-20.00 h and 20.00-21.00 h, respectively (Fig. 1).

When both sexes captured with the two traps were analyzed together in terms of the Williams' average and number of specimens (Fig. 4), Ny. neivai showed greater equivalence as between these two data, the highest number of specimens and Williams' average occurring between 20.00 and $21.00 \mathrm{~h}$, whereas no correspondence was seen between these two magnitudes for $N y$. intermedia, i.e. the maximum number of specimens was obtained between 18.00 and $19.00 \mathrm{~h}$, and two almost equivalent peaks occurred, in accordance with the Williams' average, one at 19.00-20.00 $\mathrm{h}$ and the other between 22.00 and $23.00 \mathrm{~h}$, presenting a less constant presence for the first period. Besides, the numbers of $N y$. intermedia specimens predominated over those of $N y$. neivai at the beginning and end of the period of capture, while $N y$. neivai was more frequent in the middle of the period of capture. This behavior seems to indicate differences in the ecological niche occupied by these two species.

The drier season (autumn and winter) was that in which
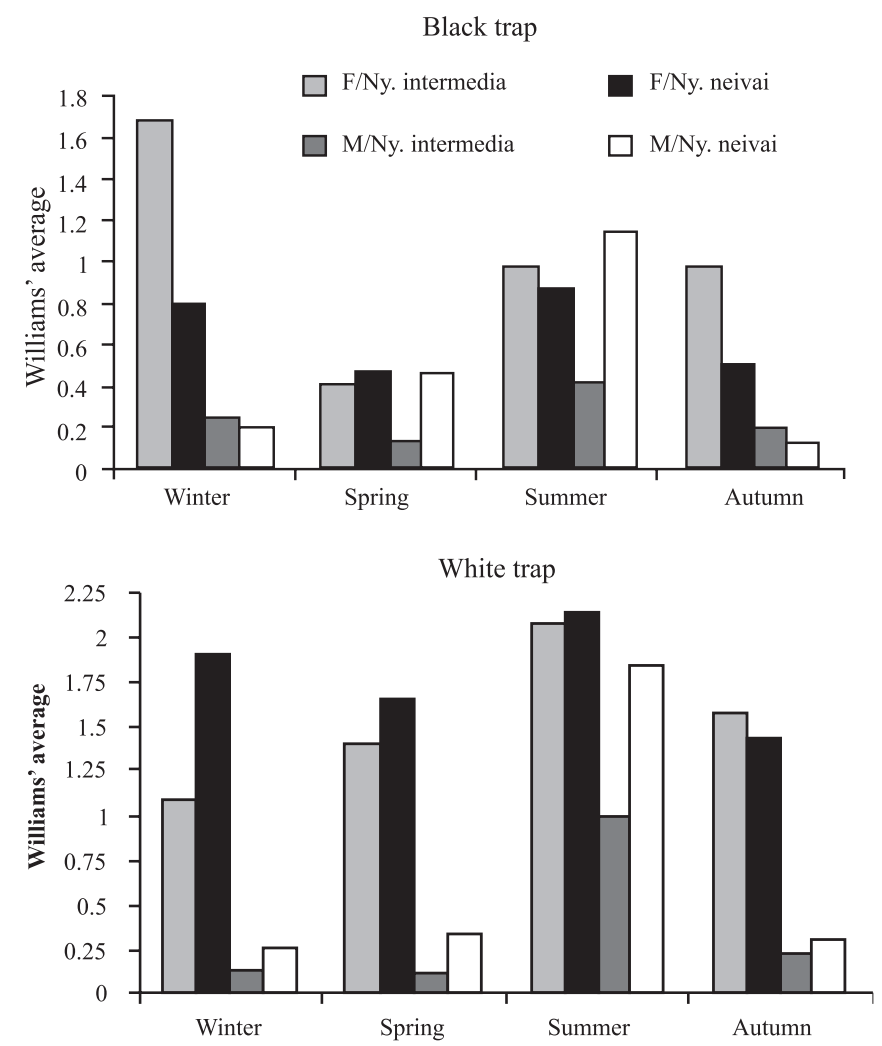

Fig. 8. Hourly average from $18.00-07.00 \mathrm{~h}$ of $\mathrm{Ny}$. intermedia and $\mathrm{Ny}$. neivai, by trap, sex and season of year, in the peridomicile, Serra district, Iporanga municipality, July 2001 - June 2002.

$N y$. intermedia was more frequent than $N y$. neivai (Fig. 7) and this superiority occurred mainly by reason of the greater attractiveness of the black trap to the females of the former species (Fig. 8). Thus, taking as premise that $\mathrm{Ny}$. intermedia is more attracted to this trap because this species is more closely associated with the forest, it is possible that in the dry period its females tend to rest in the intradomicile, the environmental conditions of which may be more closely similar to those of the forest, as it provides protection from variations in wind, temperature and humidity. So if this species presents vectorial competence to transmit Leishmania, the drier season may be considered as a period of risk for the inhabitants. On the other hand $N y$. neivai may be transmitting during more humid and hotter periods since it presents a stronger positive correlation

Table III. Frequencies of Ny. intermedia and Ny. neivai, by sex, captured with white and black Shannon traps from $18.00-07.00 \mathrm{~h}$, monthly, in the peridomicile, Serra district, Iporanga municipality.

\begin{tabular}{|c|c|c|c|c|c|c|c|c|}
\hline \multirow{3}{*}{$\begin{array}{l}\text { Sex } \\
\text { Shannon trap } \\
\text { Species }\end{array}$} & \multicolumn{4}{|c|}{ Males } & \multicolumn{4}{|c|}{ Females } \\
\hline & \multicolumn{2}{|c|}{ white } & \multicolumn{2}{|c|}{ black } & \multicolumn{2}{|c|}{ white } & \multicolumn{2}{|c|}{ black } \\
\hline & $\mathrm{N}$ & $\%$ & $\mathrm{~N}$ & $\%$ & $\mathrm{~N}$ & $\%$ & $\mathrm{~N}$ & $\%$ \\
\hline Ny intermedia & 108 & 30.0 & 58 & 30.0 & 477 & 49.7 & 374 & 63.3 \\
\hline Ny. neivai & 249 & 70.0 & 131 & 70.0 & 483 & 50.3 & 217 & 36.7 \\
\hline Total & 357 & 100.0 & 189 & 100.0 & 960 & 100.0 & 591 & 100.0 \\
\hline$\chi^{2}$ & 56.6 & & 29.1 & & 0.038 & & 41.7 & \\
\hline P & $<0.001$ & - & $<0.001$ & & $>0.05$ & & $<0.001$ & - \\
\hline
\end{tabular}


$(\mathrm{rS}=0.80$; Sig. 0.2) between frequency and monthly mean and minimum absolute temperatures.

The highest peak for both species observed in March 2002 (Fig. 5) may be a consequence of the high temperature and changes in the atmospheric conditions preceding the heavy rains (Fig. 6) that began during the capture, about $02.30 \mathrm{~h}$. These changes seemed to stimulate the flying, host-seeking activity of the sand flies, perhaps due to the greater production of carbon dioxide and odour by the humans and other animals present in the peridomiciliary area of capture.

Pi. fischeri and $\mathrm{Mg}$. migonei have frequently been associated with $N y$ intermedia and/or $N y$. neivai in São Paulo state, mainly in the Ribeira Valley (Forattini et al. 1976; Domingos et al. 1998; Gomes \& Galati 1987, 1989); however, Lu. longipalpis, the main vector of American visceral leishmaniasis, was not formerly known to occur in this region. Furthermore, its presence in the peridomicile calls for the special attention of the government organs responsible for the entomological surveillance for the control of visceral leishmaniasis.

In brief, females of $N y$. intermedia and $N y$. neivai were captured in approximately equal numbers in the anthropic environment. Females of $\mathrm{Ny}$. intermedia were much more attracted to both traps than were the males, in comparison with the difference between the two genders of $N y$. neivai. $N y$. intermedia was more attracted to the black trap than $N y$. neivai but on the white trap the two species were captured with no significant statistical difference. The males of both species were more attracted to the white trap. As for hourly rhythm, the females of $N y$. intermedia presented two higher peaks (19.00-20.00 h and 22.00-23.00 h) while $N y$. neivai presented one, at 20.00-21.00 h. Greater numbers of $N y$. intermedia than of $N y$. neivai were captured both at dusk and dawn. $N y$. intermedia was most frequent in the drier period and $N y$. neivai in the rainier season.

These differences in the behaviour of $N y$. neivai and $N y$. intermedia perhaps may be result of distinct ecological niches that they are occupying and both would be transmitting cutaneous leishmaniasis in the area, in view of their great density in the peridomicile, since in the Ribeira Valley the transmission has been identified as occurring in the domiciliary and/or the extra-forest environment.

Acknowledgements. The authors wish to express their thanks to the guide, Jânio Ribeiro de Andrade, and his family who allowed us to make the captures on their property. As also to Dr. Ademir Galati who provided the necessary logistic support. Thanks are also due to Mr. Arthur Anthony Boorne for his correction of the English text, to anonymous reviewers by their suggestions and FAPESP (processes $\mathrm{n}$. 00/06811-0 and 05/58311-5). IBAMA-SP licence (process n. 02027007000/2000-76).

\section{REFERENCES}

Aguiar, G. M; W. M. Medeiros; T. S. De Marco; S. C. Santos \& S. Gambardella. 1996. Ecologia dos flebotomíneos da Serra do Mar. I. A fauna flebotomínica e prevalência pelo local e tipo de captura (Diptera, Psychodidae, Phlebotominae). Cadernos de Saúde Pública 12: 195-206.

Andrade-Filho, J. D.; E. A. B. Galati \& A. L. Falcão. 2003. Redescription of Nyssomyia intermedia (Lutz \& Neiva, 1912) and Nyssomyia neivai (Pinto, 1926) (Diptera: Psychodidae). Memórias do Instituto Oswaldo Cruz 98: 1059-1065.

Andrade-Filho, J. D.; E. A. B. Galati \& A. L. Falcão. 2006. Polymorphism, inter-population and inter-specific variation in Nyssomyia intermedia (Lutz \& Neiva) and Nyssomyia neivai (Pinto) (Diptera, Psychodidae, Phlebotominae). Revista Brasileira de Entomologia 50: 385-393.

Andrade-Filho, J. D.; E. A. B. Galati \& A. L. Falcão. 2007. Nyssomyia intermedia (Lutz \& Neiva, 1912) and Nyssomyia neivai (Pinto, 1926) (Diptera: Psychodidae: Phlebotominae) geographical distribution and epidemiological importance. Memórias do Instituto Oswaldo Cruz 102: 481-487.

Alexander, B. 2000. Sampling methods for phlebotomine sand flies. Medical and Veterinary Entomology 14: 109-122.

Aragão, H. B. 1922. Transmissão de leishmaniose no Brasil pelo Phlebotomus intermedius. Brasília Médica 36: 129-130.

Brito, M.; C. Casanova; L. M. Mascarini; D. M. V. Wanderley \& D. M. A. Corrêa. 2002. Phlebotominae (Diptera: Psychodidae) em área de transmissão de leishmaniose tegumentar americana no litoral norte do Estado de São Paulo, Brasil. Revista da Sociedade Brasileira de Medicina Tropical 35: 431-437.

Browne, S. M \& G. F. Bennett. 1981. Response of mosquitoes (Diptera: Culicidae) to visual stimuli. Journal of Medical Entomology 18: 505-521.

Casanova, C.; R. C. Mayo; O. Rangel; L. M. Mascarini; M. G. Pignatti; E. A. B. Galati \& A. C. Gomes. 1995. Natural Lutzomyia intermedia (Lutz \& Neiva) infection in the Valley of the Mogi Guaçú River, State of São Paulo, Brazil. Boletin de la Direción de Malariología y Saneamiento Ambiental 35 (Supl 1): 77-84.

Casanova, C.; A. I. P. Costa \& D. Natal. 2005. Dispersal pattern of the sand fly Lutzomyia neivai (Diptera: Psychodidae) in a cutaneous leishmaniasis endemic rural area in Southeastern Brazil. Memórias do Instituto Oswaldo Cruz 100: 719-724.

CIIAGRO (Centro Integrado de Informações Agrometeorológicas). 2007. Atualização de dados. Available from: http://www.ciiagro.sp.gov.br/ dados/entrada.htm. (accessed 30 May 2007).

Condino, M. L. F.; S. M. P. Sampaio; L. F. Henriques; E. A. B, Galati; D. M. V. Wanderley \& F. M. A. Corrêa. 1998. Leishmaniose tegumentar americana: flebotomíneos de área de transmissão no município de Teodoro Sampaio, região sudoeste do Estado de São Paulo, Brasil. Revista da Sociedade Brasileira de Medicina Tropical 31: 355-360.

Córdoba-Lanus, E.; M. L. De Grosso; J. E. Pinero; B. Valladares \& O. D. Salomón. 2006. Natural infection of Lutzomyia neivai with Leishmania spp. in northwestern Argentina. Acta Tropica 98: 1-5.

CVE (Centro de Vigilância Epidemiológica). 2007. Leishmaniose Tegumentar Americana. Available in: http://www.cve.saude.sp.gov.br/ $\mathrm{htm} /$ zoo/lta_reg.htm. (accessed 6 June 2007).

Domingos, M. F.; G. C. Carreri-Bruno; R. M. C. Ciaravollo; E. A. B. Galati; D. M. V. Wanderley \& F. M. A. Corrêa. 1998. Leishmaniose tegumentar americana: flebotomíneos de área de transmissão, no município de Pedro de Toledo, região sul do Estado de São Paulo, Brasil. Revista da Sociedade Brasileira de Medicina Tropical 31: 425-432.

Dyar, H. G. 1929. The present knowledge of the American species of Phlebotomus Rondani (Diptera, Psychodidae) American Journal of Hygiene 10: 112-124.

Feliciangeli, M. D. 1987. Ecology of sandflies (Diptera: Psychodidae) in a restricted focus of cutaneous leishmaniasis in northern Venezuela. II. Species composition in relation to habitats, catching method and hour of catching. Memórias do Instituto Oswaldo Cruz 82: 125-131.

Forattini, O. P. \& M. R. Santos. 1952. Nota sobre infecção natural de Phlebotomus intermedius Lutz \& Neiva, 1912, por formas em leptomonas, em foco de leishmaniose tegumentar americana. Arquivos de Higiene de São Paulo 17: 171-174.

Forattini, O. P.; D. B. G. Pattoli; E. X. Rabello \& A. O. Ferreira. 1972. Infecção natural de flebotomíneos em foco enzoótico de leishmaniose no estado de São Paulo, Brasil. Revista de Saúde Pública 6: 431-433.

Forattini, O. P.; E. X. Rabello; O. P. Serra; M. D. Cotrim; E. A. B. Galati \& J. M. S. Barata. 1976. Observações sobre a transmissão da leishmaniose tegumentar no Estado de São Paulo. Revista de Saúde Pública 10: 31-43.

Galati, E. A. B. 2003. Morfologia, terminologia de adultos e identificação dos táxons da América, p. 53-175. In: Rangel, E. F. \& R. Lainson (orgs.). 
Flebotomíneos do Brasil. Rio de Janeiro, Fiocruz. 367 p.

Galati, E. A. B.; V. L. B. Nunes; M. E. C. Dorval; G. Cristaldo; H. C. Rocha; R. M. Gonçalves-Andrade \& G. Naufell. 2001. Attractiveness of black and white Shannon traps for phlebotomines. Memórias do Instituto Oswaldo Cruz 96: 641-647.

Giatti, L. L.; A. A. Rocha; F. A. Santos; S. C. Bitencourt \& S. R. M. Pieroni. 2004. Condições de saneamento básico em Iporanga, Estado de São Paulo. Revista de Saúde Pública 38: 571-577.

Gibson, G. \& S. J. Torr. 1999. Visual and olfactory responses of haematophagous Diptera to host stimuli. Medical Veterinary and Entomology 13: 2-23.

Gomes, A. C.; E. X. Rabello; J. L. F. Santos \& E. A. B. Galati. 1980. Aspectos ecológicos da leishmaniose tegumentar americana, 1. Estudo experimental da freqüência de flebotomíneo e ecótopos artificiais com referência especial a Psychodopygus intermedius. Revista de Saúde Pública 14: 540-556.

Gomes, A. C.; E. X. Rabello; J. L. F. Santos \& E. A. B. Galati. 1982. Aspectos ecológicos da leishmaniose tegumentar americana. 2. Ecótopo artificial como abrigo de Psychodopygus intermedius e observações sobre alimentação e reprodução sob influência de fatores físicos naturais. Revista de Saúde Pública 16: 149-159.

Gomes, A. C. \& E. A. B. Galati. 1987. Aspectos ecológicos da Leishmaniose Tegumentar Americana. 5. Estratificação da atividade espacial e estacional de Phlebotominae (Diptera, Psychodidae) em áreas de cultura agrícola da região do Vale do Ribeira, Estado de São Paulo, Brasil. Memórias do Instituto Oswaldo Cruz 82: 467-473.

Gomes, A. C. \& E. A. B. Galati. 1989. Aspectos ecológicos da leishmaniose tegumentar americana. 7. Capacidade vetorial flebotomínea em ambiente florestal primário do Sistema da Serra do Mar, região do Vale do Ribeira, Estado de São Paulo. Revista de Saúde Pública 23: 136-142.

Gomes, A. C.; E. X. Rabello; J. L. F. Santos \& E. A. B. Galati. 1983. Aspectos ecológicos da leishmaniose tegumentar americana. 3. Observações naturais sobre o ritmo diário de Psychodopygus intermedius em ambiente florestal e extra-florestal. Revista de Saúde Pública 17: 23-30.

Gomes, A. C.; J. M. S. Barata; E. O. Rocha e Silva \& E. A. B. Galati. 1989. Aspectos ecológicos da Leishmaniose Tegumentar Americana. 6. Fauna flebotomínea antropófila de matas residuais situadas na região centronordeste do Estado de São Paulo, Brasil. Revista de Instituto de Medicina Tropical de São Paulo 31: 32-39.

Gomes, A. C.; J. L. F. Santos \& E. A. B. Galati. 1986. Ecological aspects of American cutaneous leishmaniasis. 4 - Observations on the endophilic behavior of the sand-fly and the vectorial role of Psychodopygus intermedius in the Ribeira Valley region of the S. Paulo State, Brazil. Revista de Saúde Pública 20: 280-287.

Haddow, A. J. 1960. Studies on the biting-habits and medical importance of East African mosquitos in the genus Aedes. I. Subgenera Aedimorphus, Banksinella and Nunnius. Bulletin of Entomological Research 50: 59-779.

Karmann, I. \& J. A. Ferrari. 2002. Carste e Cavernas do Parque Estadual Turístico do Alto Ribeira (PETAR), SP - Sistemas de cavernas com paisagens subterrâneas únicas. p. 401-413. In: C. Schobbenhaus; D. A. Campos D. A; E. T. Queiroz; M. Winge; M. L. C. Berbert-Born MLC (edits.) Sítios Geológicos e Paleontológicos do Brasil. 1. ed., v.1, Brasília, DNPM/CPRM - Comissão Brasileira de Sítios Geológicos e Paleobiológicos (SIGEP), $554 \mathrm{p}$.

Killick-Kendric, R. 1990. Phlebotomine vectors of the leishmaniases: a review. Medical and Veterinary Entomology 4: 1-24.

McIver, S. B. 1982. Review article: sensillae of mosquitoes. Journal of Medical Entomology 19: 489-535.

Marcondes, C. B. 1996. A redescription of Lutzomyia (Nyssomyia) intermedia (Lutz \& Neiva, 1912), and L. neivai (Pinto, 1926) (Diptera, Psychodidae, Phlebotominae). Memórias do Instituto Oswaldo Cruz 91: 457-462.

Marcondes, C. B. \& P. S. S. Borges. 2000. Distinction of males of the Lutzomyia intermedia (Lutz \& Neiva, 1912) species complex by ratios between dimensions and by an artificial neural network (Diptera: Psychodidae: Phlebotominae). Memórias do Instituto Oswaldo Cruz 95: $685-688$.

Marcondes, C. B.; A. L. Lozovei \& J. H. Vilela. 1998. Distribuição geográfica de flebotomíneos do complexo Lutzomyia intermedia (Lutz \& Neiva, 1912) (Diptera, Psychodidae). Revista de Sociedade de Medicina Tropical 31: 51-58.

Massafera, R.; A. M. Silva; A. P. Carvalho; D. R. Santos; E. A. B. Galati \& U. Teodoro. 2005. Fauna de flebotomíneos do município de Bandeirantes, no Estado do Paraná. Revista de Saúde Pública 39: 571-577.

Nimer, E. 1977. Geografia do Brasil - Região Sudeste. Rio de Janeiro, IBGE, $667 \mathrm{p}$.

Paiva, B. R.; N. F. Secundino; J. C. Nascimento; P. F. Pimenta; E. A. B Galati; H. Ferreira-Junior \& R. S. Malafronte. 2006. Detection and identification of Leishmania species in field-captured phlebotomine sandflies based on mini-exon gene PCR. Acta Tropica 99: 252-259.

Pinto, C. 1930. Arthropodos parasitos e transmissores de Doenças. Tomo II, Phlebotomos, p. 491-538. Bibliotheca Scientifica Brasileira, Collecção Medico-Cirurgica n. 117. Rio de Janeiro, Editora Pimenta de Mello e Companhia, 845 p.

Pinto, M. C.; D. H. Campbell-Lendrum; A. L. Lozovei; U. Teodoro \& C. R. Davies. 2001. Phlebotomine sandfly responses to carbon dioxide and human odour in the field. Medical and Veterinary Entomology 15: 132-139.

Pita-Pereira, D.; C. R. Alves; M. B. Souza; R. P. Brazil; A. L. Bertho; A. F. Barbosa \& C. Britto. 2005. Identifications of naturally infected Lutzomyia intermedia and Lutzomyia migonei with Leishmania (Viannia) braziliensis in Rio de Janeiro (Brazil) revealed by a PCR multiplex nonisotopic hybridization assay. Transactions of the Royal Society of Tropical Medicine and Hygiene 99: 905-913.

Rangel, E. F. \& R. Lainson. 2003. Ecologia das leishmanioses. Transmissores de Leishmaniose Tegumentar Americana, p. 291-336. In: Rangel, E. F. \& R. Lainson (orgs.). Flebotomíneos do Brasil. Rio de Janeiro, Fiocruz, $367 \mathrm{p}$.

Rangel, E. F.; N. A. Souza; E. D. Wermelinger \& A. F. Barbosa. 1984. Infecção natural de Lutzomyia intermedia Lutz \& Neiva, 1912 em área endêmica de leishmaniose tegumentar no estado do Rio de Janeiro. Memórias do Instituto Oswaldo Cruz 79: 395-396.

SIGRH (Sistema de Informações para o Gerenciamento de Recursos Hídricos do Estado de São Paulo). 2007. Banco de dados pluviométricos do Estado de São Paulo. Available from: http://www.sigrh.sp.gov.br/cgibin/bdhm.exe/plu?qwe=qwe. (accessed 6 June 2007).

Souza, N. A.; C. A. Andrade-Coelho; M. L. Vilela \& E. F. Rangel. 2001. The Phlebotominae sand fly (Diptera: Psychodidae) fauna of two rain forest reserves in the state of Rio de Janeiro, Brazil. Memórias do Instituto Oswaldo Cruz 96: 319-324.

Souza, N. A.; C. A. Andrade-Coelho; V. C. Silva; A. A. Peixoto \& E. F. Rangel. 2005. Moonlight and blood-feeding behaviour of Lutzomyia intermedia e Lutzomyia whitmani (Diptera: Psychodidae: Phlebotominae), vectors of American cutaneous leishmaniasis in Brazil. Memórias do Instituto Oswaldo Cruz 100: $39-42$.

Taniguchi, E. H.; J. E. Tolezano; R. Larosa; C. R. Elias \& E. A. B. Galati. 2002. Observações ecológicas de flebotomíneos em área endêmica de leishmaniose tegumentar americana (LTA) no município de Eldorado, Vale do Ribeira, Estado de São Paulo, Brasil, 1996-1997. I - Sazonalidade e freqüência de L. ayrozai em diferentes ecótopos com animais sentinelas em ambiente florestado. Revista do Instituto Adolfo Lutz 61: 103-112.

Teodoro, U.; V. La Salvia Filho; E. M. Lima; N. M. Misuta; T. G. Verginassi \& M. E. M. C. Ferreira. 1991. Leishmaniose tegumentar americana: flebotomíneos de área de transmissão no Norte do Paraná, Brasil. Revista de Saúde Pública 25: 129-133.

Received 08/12/2008; accepted 14/10/2010

Editor: Vanete Thomaz Soccol 